\title{
Uses of Justicia spicigera in medicine and as a source of pigments
}

\author{
Itzamná Baqueiro-Peña and José A. Guerrero-Beltrán
}

Depto de Ing. Química, Alimentos y Ambiental. Universidad de las Américas Puebla Cholula, Puebla 72820, México

Corresponden autor: Prof. José A. Guerrero-Beltrán, Depto. de Ing. Química, Alimentos y Ambiental, Universidad de las Américas Puebla, Cholula, Puebla 72810, México

Submission date: July 8, 2014; Acceptance date: September 4, 2014; Publication date: September 6,2014

\begin{abstract}
Justicia spicigera (muicle) is a plant that has been used from the pre-Hispanic era to contemporary times in Mexico. It has been used in the traditional medicine for healing diseases such as dysentery, diabetes, leukemia, and anemia, just to mention some human disorders. It has been used for obtaining indigo dye after making extraction with water to be used for coloring of baskets, crafts, and clothes. The pigments, as a powder, have been studied for use for coloring foods. The dyeing characteristics of the J. spicigera pigments have antioxidant properties due to the flavonoids content. Since this plant has been used for making infusions to people for curing some physical disorders, today J. spicigera is being studied to take advance of its dyeing and antioxidant properties to be used in the food and pharmaceutical industries.
\end{abstract}

Key words: Justicia spicigera (muicle), antioxidants, traditional medicine, pigments for foods, indigo, phytochemicals

\section{INTRODUCTION}

The muicle (Justicia spicigera) plant is a shrub that grows in Mexico, Central America and some areas of the United States of America. This plant has been used, since pre-Hispanic times, as a dye for crafts and paintings and in traditional medicine, not only in Mexico but also in Guatemala and in some areas of the United States of America. In seeking to elucidate the different chemical compounds found in J. spicigera, studies have been conducted for accomplish different objectives. Euler and Adam [1], Domínguez et al. [2] and Sepúlveda-Jiménez et al. [3] studied phytochemicals in J. spicigera; however, these studies were focused on the pharmacological properties because of the need to find alternatives to the existing drugs against certain disorders in humans [4]. In traditional medicine and pharmacology, the studies of $J$. spicigera have been focused on diseases such as diabetes $[5,6]$, different types of cancers $[7,8$, $9,10]$, and infectious diseases such as gonorrhea [11], giardiasis [12], and fascioliasis [13]. The dyeing properties of this plant have also been investigated [14] due to the use of the plant 
pigments in various Mexican crafts and fabrics in order to establish the similarities and differences of indigo [14] with the intention of including it in foods [15].

This paper presents the phytochemical and pharmacological studies of J. spicigera as well as generalities, uses, and applications in the traditional medicine and its use as a natural pigment.

\section{Justicia spicigera}

Justicia spicigera (Mexican honeysuckle) is a dicotyledonous plant belonging to the acanthaceae family. J. spicigera is popularly known by various names: Chak lool, ts'i'its, get ink, bisil k'aax, cross k'aax tsiits, and ichkan in Maya in the Yucatan Peninsula; andichkaan Caandathana in Popoluca in Veracruz; grass and grass indigo ink in Oaxaca; charatzicua in Tarascan in Michoacán; micle, mohintle, mohintli and mohuite in Hidalgo; moitli, mayotte, moyotli, mozote, and muh in the Huasteca in San Luis Potosí; muicle in Jalisco; muitle if-is, trumpet, and blue grass in Veracruz, and tsi'is anduhaa-ink-Spanish in Zapotec in Oaxaca states in Mexico[16, 17].

Distribution in the world

J. spicigera is a plant native of Mexico and Central America. It can be found in Belize, El Salvador, Honduras, Costa Rica, and Nicaragua. In Mexico, J. spicigera grows in the states of Chiapas, Nayarit, San Luis Potosi, Mexico, Puebla, Morelos, Tlaxcala, Yucatan, and Hidalgo [18]. This plant grows well in warm, semidry, dry and mild climates, from the sea level to 3000 meters over the sea level. It is cultivated in gardens and along the roads. It is associated with disturbed vegetation in tropical, deciduous, semi-deciduous, and evergreen forests; a well as in desert, thorn forest, cloud forest, and oak and mixed pine and oak-pine woodlands [17, 19].

\section{Taxonomy}

The acanthaceae family gathers 256 genera and 277 species that may grow in tropical and subtropical areas. Table 1 shows the taxonomic classification of the J. spicigera species [18].

Table 1: Taxonomic classification of Justicia spicigera. ${ }^{1}$

\begin{tabular}{ll}
\hline Subkingdom & Thracheobionta \\
Division & Magnoliophyta \\
Class & Magnoliopsida \\
Subclass & Asteridae \\
Order & Scrophulariles \\
Family & Acanthaceae \\
Gender & Justicia \\
Species & spicigera Schltdl \\
\end{tabular}

${ }^{1}$ Mendoza-Zúñiga [18]

Morphology

The J. spicigera plant is a densely branched shrub of about 1 to $1.5 \mathrm{~m}$ in height. Its veiny leaves are longer than wide. The flowers are grouped at the end of the junction of the stem and leaf. The 
orange or red small flowers are shaped like long "trumpets" similar to an arum lily; the fruits are capsules [17].

\section{Phytochemicals}

There are various reports published regarding J. spicigera. Researchers have focused the investigation on pharmacological studies due to the use of this plant in traditional medicine; however, the J. spicigera phytochemical studies have not been investigated in depth.

In J. spicigera are various chemicals such as simple carbohydrates, mucilages, pectins, glycosides, pigments, resin, essential oils and minerals (potassium, calcium acetate and oxalate, sulfate and sodium chloride). Phenolic compounds, from the secondary metabolism of the plant, have also been found. Flavonoids such as kaempferitrin, and kaempferol trirhamnoside have been isolated from leaves and tannins from flowers [20].

The concentration of total phenols, flavonoids and antioxidant activity in J. spicigera were reported by Sepúlveda-Jiménez et al. [3]. In the total phenols analysis of extracts of plant parts, it was found that the aqueous extract of the flower had the highest total phenolic content $(5.01 \pm$ $0.02 \mathrm{~g}$ Gallic acid equivalents/100 $\mathrm{g}$ dry matter) than in leaves and stems. They also observed a higher content of flavonoids in the methanol extract of stems $(1.30 \pm 0.07 \mathrm{~g}$ catechin equivalents $/ 100 \mathrm{~g}$ dry matter) and a higher antioxidant activity in methanolic extracts of leaves $\left(\mathrm{IC}_{50} 48.86 \pm 1.25 \mu \mathrm{g}\right.$ extract/mL). Furthermore, García-Márquez et al. [21] studied the effect of the type of solvent and extraction temperature on the antioxidant activity and total phenols content in J. spicigera and its losses during storage at different $\mathrm{pHs}$. They found that aqueous solvents obtained at 25 and $60^{\circ} \mathrm{C}$ deliver extracts with high concentrations of phenolic compounds (190-1019 mg Gallic acid equivalents/kg of J. spicigera) and high antioxidant capacity (6.55 mM Trolox equivalents).

Euler and Adam [1] analyzed extracts of J. spicigera with the ${ }^{1} \mathrm{H}-\mathrm{NMR}$ and GC-S techniques as well as the UV spectroscopy. They found trirhamnosides of kaempferol and kaempferitrin, compounds that might be useful for the treatment of hypertension [22]. Domínguez et al. [2] identified in hexane-isopropyl ether-methanol extracts of J. spicigera $\beta$ sitosterol, 3-O - glucoside of $\beta$ - sitosterol and cryptoxanthin I (a very polar anthocyanin that imparted fluorescence to the extracts). They confirmed the presence of kaempferitrin.

\section{Use in the traditional medicine}

Since ancient times, humans have used seeds, roots, stems, flowers, and fruits of plants for feeding and healing disorders due to their effectiveness, availability, and low cost. Traditional medicine has been the basis for integrating the worldwide pharmacopoeia. A number of active chemical compounds, from the therapeutic point of view, have been extracted from plants; however, many of them are now synthesized in the laboratory. Historically, numerous activities of the traditional medicine are well documented in manuscripts, paintings, and other documents in the literature. In many cases, the conquistadors and missionaries, Spanish in Mexico, collected plants and remedies to be studied and used in colonial times. In Mexico, the Badiano Codex collect information about various diseases suffered by Mesoamerican natives and cures; in the document are remedies for fever, pulmonary tuberculosis, diarrhea, hemorrhoids, intestinal parasites, rheumatism, bone disease, arthritis, cough, deafness, skin problems, and diseases of the 
eye. All of these disorders were alleviated using various parts of plants treated in different ways [23]. The extensive knowledge of traditional medicine and native plants of Mexico has lasted throughout the time. There are reports of the properties of plants from different parts dating back to pre-Hispanic times.

In Mexico, of the 23,400 vascular plants, 500 species are used for medicinal purposes. About $90 \%$ of Mexican people have used, or still use, plants to treat various ailments [24]. However, the botanical diversity used for healing in the various regions of the country may vary. For example, in Hidalgo, Mexico, the most commonly used species are coleus (Coleus blumei), plantain (Plantago australis), and sweet grass (Lippia dulcis) for gastrointestinal problems; borage (Borago officinalis), fennel (Foeniculum vulgare), and Tasmanian blue gum (Eucalyptus globulus) for breathing problems; silk flower or Mexican brush (Ageratum houstonianum) and Conabio (Solanum nigrescens) for skin problems [25]. In San Luis Potosi, Mexico, sweet or Maroon chamomile (Matricaria recutita) is the plant most used in combination with other plants for curing same problems as well as herb-of-grace (Ruta graveolens), marigold (Tagetes erecta), basil (Ocimum basilicum) and Mexican fleabane (Erigeron karviskianus) [24]. For J. spicigera, in the colonial period of the XVI century, Francisco Hernández describes the use of this plant to cure scours and was also used as antiescabies, antigonorrheal, antipyretic, and for metrorrhagia. In the twentieth century, Maximino Martínez cites, J. spicigera was used as scours, antiepileptic, antiscabies, antidiarrheal, antispasmodic, stimulant, to control metrorrhagia, to strengthen the nerves, and useful in menopause [17]. Today, J. spicigera is used for several purposes: to prepare infusions for releasing headaches, to treat certain problems of the circulatory system, to control anemia and poor circulation, to lower blood pressure, to treat skin problems such as rashes, varicose veins, sores, spots and petty, to be used as an antitussive, to shower neonates, and to treat digestive dysentery and epilepsy. It is also used for helping to improve certain disorders of the digestive system, diarrhea, vomiting, and stomach aches, as well as for cancer, menstrual disorders, urinary infections, menstrual irregularities, and dizziness [16, 26]. As already mentioned, the use of medicinal plants has been one of the main ways to address health problems in Mexico. This practice dates back to ancient times, but today it is still used in domestic and marginalized populations due to lack of medical services. In Mayan, Nahuatl, Mixe and Zapotec ethnic groups, Heinrich et al. [27] investigated the use of some medicinal plants and these were grouped according to the healing of skin, respiratory, and gastrointestinal problems.

A common practice in Mexican traditional medicine is the combination of various plants or plant parts. Plants with the combination of the various curative components may exert a positive effect on the health of individuals. Perusquia et al. [28] reported that the use of an infusion prepared with J. spicigera and walnut leaves may purify the blood and increases red blood cells. A variation for this infusion is the addition of sarsaparilla, used to treat heart disorders.

\section{Pharmacological characteristics}

In recent years, the interest in studying and understanding components of plants with healing properties has been increased. The interest has been focused in obtaining biologically active molecules and using them for curing various diseases.

There are many uses of J. spicigera in the Mexican traditional medicine. Thus, the interests of many researchers have aroused to demonstrate the healing properties of plants and identify the 
mechanisms by which molecules can have a health benefit for humans. The studies that have been conducted with $J$. spicigera are about diabetes, various types of cancer, sexually transmitted infections, and infections where flatworms, protozoa, mites are involved. It has also been used as an antimicrobial against various species of bacteria and fungi.

\section{Gonorrhea}

In 1996, the World Health Organization (WHO) estimated that of 250 million of sexually transmitted diseases cases, $10 \%$ were of gonorrhea (diseased by the gonococcus Neisseria gonorrhoeae). Currently, it has been reported a reappearance of this disease and it has been observed a fastidious resistance to the usual treatments with quinolones and cephalosporins [29]. Cáceres et al. [11] conducted a study on 101 extracts of plants where J. spicigera was included; in this study, the inhibition of $N$. gonorrhoeae on plates was tested. The study of the inhibition of $N$. gonorrhoeae by $J$. spicigera extracts showed lower inhibition ( $8 \mathrm{~mm}$ in diameter) compared to extracts from achiote (Bixa orellana), guajilote (Parmentiera edullis) guachipilin leaves (Diphysa robinioides Benth.), Siam weed (Chromolaena odorata), gliricidia (Gliricidia sepium), cutleaf ground cherry (Physalis angulata), matico (Piper aduncum), root extracts of white sapote (Casimiroa edullis) and clematis (Clematis dioica) which showed inhibition up to 9 and $17 \mathrm{~mm}$ in diameter.

\section{Oral diseases}

Other types of infections where J. spicigera has been used are the oral diseases caused by the Streptococcus mutans and Porphyromonas gingivalis bacteria. Rosas-Piñon et al. [30], obtained ethanol extracts of 47 plants from the Mexican plateau region and were used to inhibit these bacteria. Extracts of avocado (Persea americana Mill), clove (Syzygium aromaticum), cinnamon (Cinnamomum zeylanicum), and Rhus standleyi showed a minimum inhibition at concentrations in the range of $10.5-78 \mathrm{mg} / \mathrm{mL}$ compared to the minimum inhibitory concentration of $J$. spicigera ethanol extracts $(1000 \mathrm{mg} / \mathrm{mL})$.

\section{Dysentery}

Vega-Ávila et al. [31] analyzed the antibacterial and antifungal activity of ethanol and hexane $J$. spicigera extracts. They analyzed the minimum inhibitory concentration of the extracts by the resazurin method. The ethanol extract, at concentrations around $2.5 \mathrm{mg} / \mathrm{ml}$, inhibited the growth of Shigella flexneri, Salmonella typhi, Salmonella typhimurium, Escherichia coli, and Staphylococcus aureus. The hexane extracts, at concentrations of about $1.25 \mathrm{mg} / \mathrm{mL}$, inhibited the above mentioned bacteria as well as Candida albicans with a concentration of $0.25 \mathrm{mg} / \mathrm{mL}$. These results show the effectiveness of J. spicigera in inhibiting microorganisms that cause dysentery, in addition to support the empirical theories of the use of J. spicigera in the Mexican traditional medicine to cure this condition.

\section{Parasites}

J. spicigera has also been used to treat diseases produced by protozoa. The giardiasis is a disease caused by Giardia lamblia or Giardia duodenalis, a flagellate pathogen protozoan, which may parasitizes the upper small intestine. The symptoms are varied, giardiasis may cause mucous 
diarrhea, abdominal pain, nausea, headache, flatulence and even may cause malabsorption of nutrients [32]. Giardiasis treatments includes the use of 5-nitroimidazole, benzimidazole, nitrofurans and quinacrine. However, these drugs have some undesirable side effects; therefore, the implementation of alternative therapies becomes necessary to treat these conditions. PerazaSánchez et al. [12] reported in 2002, in the Yucatan Peninsula, Mexico, an outbreak of 3,512 persons out of 100,000 inhabitants who acquired giardiasis. J. spicigera has been used in the Mexican traditional medicine for the treatment of diarrhea of various origins. Ponce-Macotela $e t$ al. [33] conducted a study exposing Giardia duodenalis to different concentrations (41-250 $\mu \mathrm{g})$ of $J$. spicigera ethanol extracts for $2 \mathrm{~h}$ at $37^{\circ} \mathrm{C}$. Tubes in which the assay was performed were centrifuged and the cells obtained were grown in TYIS33 culture medium at $37^{\circ} \mathrm{C}$. Every 24 hours along a week, some tubes were centrifuged to perform cell counting using a hemocytometer. An irreversible damage of G. lamblia trophozoites was observed. The cells had damage in the nucleus and the membranes, holes in the nucleus and cytoplasm. Ribosomes were displaced and in some places there were accumulations of ribosomes. Some tubes having trophozoites were analyzed weekly; however, no cell growth was observed. Peraza-Sánchez et al. [12] prepared extracts of 10 native plants from the Yucatan Peninsula to evaluate the effect on the Giardia lamblia recovering and growth. The plants were: nance (Byrsonima crassifolia (L.) Kunth), dentate cupania (Cupania dentata DC.) diphisa (Diphysa carthagenensis Jacq.) dorstenia (Dorstenia contrajerva L.), gliricidia (Gliricidia sepium Jacq. Kunth ex Walp.), muicle (J. spicigera Schldl.), shrubby camphorweed (Pluchea odorata L. Cass.), wormgrass (Spigelia anthelmia L.), tridax daisy (Tridax procumbens L.), and Sacramento burbark (Triumfetta semitriloba Jacq.). The ten extracts showed activity against trophozoites of G. lamblia. Plants with increased activity were $T$. procumbens $\mathrm{L}$. ( $\mathrm{IC}_{50}$ of $\left.6.34 \mu \mathrm{g} / \mathrm{mL}\right), C$. dentata $(7.59 \mu \mathrm{g} / \mathrm{mL})$, D. carthagenensis $(11.53 \mu \mathrm{g} / \mathrm{mL})$, and B. crassifolia $(15.55 \mu \mathrm{g} / \mathrm{mL})$. In this study, the extracts of J. spicigera showed an $\mathrm{IC}_{50}$ of $117.43 \mu \mathrm{g} / \mathrm{mL}$, similar to datum reported by Ponce-Macotela et al. [33], ( $\left.\mathrm{IC}_{50} 125 \mu \mathrm{g} / \mathrm{mL}\right)$.

\section{Antidiabetes}

Andrade-Cetto and Heinrich [5] reported that infusions of J. spicigera decrease the hypoglycemia of blood. Ortíz-Andrade et al. [6] conducted a study on the hypoglycemic effect of muicle (J. spicigera) in rats. They evaluated the ethanol extracts effect and found a reduction of glucose levels in blood in normoglycemic rats; the glucose reduction was observed between 0.5 and 4 hours after administering the extract of J. spicigera. Results from this study were comparable with those obtained with glibenclamide, repaglinide and saxagliptin; drugs used in the treatment of type 2 diabetes. Results of this study suggested that the J. spicigera antidiabetic effect is because of the stimulation of glucose uptake in adipocytes sensitive and insulin resistant. These results are encouraging because, since 1987, this disease is the fifth cause of death in the United States of America. In 2002 there were 224,092 deaths due to this disease and in $201015 \%$ of all deaths in the USA was due to this condition [34]. Therefore, J. spicigera could be used as an alternative therapy for all patients with this condition.

\section{Anticancer}


J. spicigera has been also used to treat cancer. In the United States, 1 in 4 deaths are due to cancer. The most common cancer in women is the breast cancer. Globally, in 2002 there were 1,151,298 new cases; 410,712 patients died and today there are 4.4 million of women with this condition [35]. According to the World Health Organization, cervical cancer is the second cause of death among women worldwide, with 300 deaths per year. Eighty percent of the cases occur in the developing countries and about 500,000 new cases occur each year. In Mexico, in 2002, there were 12,512 new cases of cervical cancer, of which about $46 \%$ ended to death $[36,35]$. The study of the effect of $J$. spicigera on cancer cells has been the central part of various pharmacological investigations. Vega-Ávila et al. [8] studied the extracts of dried J. spicigera on some cancer cells. They performed the extraction with hexane, dichloromethane, ethyl acetate and water; solvents were evaporated and residue resuspended in ethanol or water. Extracts were assessed in human breast T47D cancer cells and HeLa cervical cancer cells. The ethanol extract of $J$. spicigera showed cytotoxic activity in T47D cells, showing an $\mathrm{ED}_{50}$ of $0.43 \mathrm{mg} / \mathrm{mL}$ which is greater than colchicine $\left(\mathrm{ED}_{50}=2.89 \mathrm{mg} / \mathrm{mL}\right)$ that is used as an antitumor drug. In the HeLa cell line of uterine cancer, increased cytotoxic activity was observed with colchicine $\left(\mathrm{ED}_{50}=\right.$ $0.341 \mathrm{mg} / \mathrm{mL})$ compared with the ethanol extract of J. spicigera $\left(\mathrm{ED}_{50}=5.59 \mathrm{mg} / \mathrm{mL}\right)$. JacoboSalcedo et al. [9] reported that extracts of J. spicigera and Phoradendron serotinum have cytotoxic to breast cancer cells $\left(\mathrm{IC}_{50}<30 \mu \mathrm{g} / \mathrm{mL}\right.$ ) type MCF7 and HeLa.

Fernández-Pomares et al. [10] assessed ethanol/water of J. spicigera extracts on LNCaP prostate cancer cells. They observed an antiproliferative effect of cells by direct counting with the MTT (3 - (4, 5-dimethylthiazol-2-yl) -2, 5-diphenyl tetrazolium bromide) method. Authors recommend the use of this extract as a potential antitumor agent that could be used in the treatment of prostate cancer. This type of cancer is more common in men over 50 years and represents $29 \%$ among different types of cancer, and in Mexico is the leading cause of death in men; in 2011 a mortality of 13 per 100,000 inhabitants was observed [37].

\section{Antileukemia}

Leukemia, known as hematological cancer, comprises a group of diseases that occur in myeloid, erythroid, megakaryocytic, and monocytic precursor cells. Leukemia caused by a clonal transformation of hematopoietic precursors by acquiring chromosomal rearrangements and multiple gene mutations. In the United States, the incidence is 8 cases per 100,000 individuals a year, from which 6,500 are children and adolescents. It has been observed higher incidence in the Latin American population [38]. The identification and the study of the mechanism of action of compounds from plants like $J$. spicigera are highly relevant to propose therapies in patients with hematopoietic disorders [7].

\section{Antianemia}

J. spicigera infusion is popularly used as a remedy for anemia and during menstrual periods [23]. It is believed that J. spicigera exerts a proliferation and differentiation of erythroid progenitors. Cáceres-Cortés et al. [7] studied the effect of extracts of J. spicigera different hematopoietic cells: human leukemic cell lines, cells from umbilical cord blood, and bone marrow cells of mouse. Analysis of colony formation by the MTT (3-(4, 5-dimethylthiazol-2-yl)-2, 5-diphenyl 
tetrazolium bromide) method, determined the cytotoxic activity of extracts of J. spicigera on leukemic cells; they did not observe hematopoietic cell proliferative activity.

\section{Alternative therapies}

Alternative therapies (AT) has been used for curing several diseases. Herrera-Arellano et al. [4] reported that this is common in people infected with the human immunodeficiency virus (HIV). Authors reported that of all patients with HIV, 73.4\% use AT of which $29.7 \%$ use the herbs. Among the plants used are cat's claw (Uncaria tomentosa) (11.25\%) and J. spicigera $(4.49 \%)$. The main use of $J$. spicigera is in infusions due to its anti-inflammatory properties.

\section{Use in animals}

The use of $J$. spicigera in the Mexican traditional medicine has also been explored for controlling of cattle and sheep diseases. Fascioliasis is a parasitic infection caused by the trematode Fasciola hepatica which mainly infects sheep and cattle, the man being a host. It has been reported an increased incidence of fascioliasis in different countries [39]; so that, researching in the use of plants and their products has been an alternative for controlling this disease. Ibarra-Moreno et al. [13] evaluated the activity of extracts of yarrow (Achillea millefolium), wormwood (Artemisia absinthium), Mexican wormwood (Artemisia mexicana), bitter-trunk (Castela tortuosa), fetid goosefoot (Chenopodium graveolens), straw (Gymnosperma glutinosum), muicle (J. spicigera), lemon verbena (Aloysia citriodora), Mexican oregano (Lippia graveolens), peppermint (Mentha x piperita), abele (Populus alba), and thyme (Thymus vulgaris) obtained with hexane and then concentrated. From concentrated ethanol extracts at concentrations of $50,125,250$ and $500 \mathrm{mg} / \mathrm{L}, 2$ to $5 \mu \mathrm{L}$ were mixed of methyl cellulose in the range 998-995 $\mu \mathrm{g}$ as a vehicle; mixtures were given orally to mice CD- ${ }^{\circledR}$. Mice were observed for 20 days and their appetite, hair appearance, muscular movements, and mucus were observed. It was observed that the ethanol extracts of yarrow (Achillea millefolium), bitter-trunk (Castela tortuosa) and peppermint (Mentha x piperita) were lethal to mice at a minimum dose of 125 $\mathrm{mg} / \mathrm{L}$, while the ethanol extracts of muicle (J. spicigera) and Mexican oregano (Lippia graveolens) were lethal at doses $250 \mathrm{mg} / \mathrm{L}$. Ethanol extracts of wormwood (Artemisia absinthium), fetid goosefoot (Chenopodium graveolens), straw (Gymnosperma glutinosum), lemon verbena (Aloysia citriodora), abele (Populus alba), and thyme (Thymus vulgaris), had a minimum lethal dose of $500 \mathrm{mg} / \mathrm{L}$ to mice. In order to know the effect on liver and kidneys of mice, doses were tested with higher concentrations of the extracts $(500 \mathrm{mg} / \mathrm{kg})$; therefore, histopathological studies were performed. No evidence of any damage to those organs was observed. Authors concluded that the extracts are not harmful to mammals and that they can be administer to hosts of Fasciola hepatica.

\section{Pigments and handcrafts}

In Mexico, basketry making using parts of plants is an ancient practice. For basketry, about 80 species such as agaves, canes, palms, yucca, tule, willow, and others are used. For decorating, plants of the genus Justicia spp. (black dye) are used. The Justicia spicigera (red dye) leaves are used to produce a blue to red dye, which is used to decorate baskets of reed. The J. spicigera leaves are boiled, for one night or one day, along with material to be colored in copper containers 
[40]. J. spicigera is considered as one of the most ancient plants used among artisan weavers in Santa Maria Atzompa, Oaxaca, Mexico. They use J. spicigera or "ink leaf" for obtaining a bluegray color; however, this color may fade when used alone [41]. It is also used widely in northern Veracruz (Veracruz Huastec), Mexico for the decoration of basketry. In Chicontepec, Veracruz, $87.5 \%$ of $J$. spicigera production is used for dyeing basketry. While in Hueycuatitla, Veracruz, the percentage of J. spicigera used for the same purpose is around 30\%. Trueba-Sánchez [42] pointed out that $J$. spicigera was used as a dye during colonial and pre-Hispanic times by the Huasteca, Maya and Nahuatl cultures. Macerated leaves and stems produce a blue-purple dye which is used to obtain various hues of blue. The dye was also used in the colonial art, specifically paintings [43]. J. spicigera is also used for coloring crafts in violet. It is also used to stain white clothes in Yucatan, Campeche, and Quintana Roo states in Mexico [16].

\section{Pigments analysis}

The molecules of various plant dyes used in the pre-Hispanic and colonial times have been analyzed for identification. Casanova-González et al. [14], using the technique of surface enhanced Raman spectroscopy (SERS), obtained for the first time the tridimensional spectrum of J. spicigera extract. Although the structure of the main component of this dye has not been determined yet, it is believed that the blue color is due to indigo which has been the most used dye in the history of mankind due to its blue color. Indigo dye was extracted from plants of the genus Indigofera sp; however, today it is currently obtained through chemical synthesis. It has been observed a clear difference between indigo and $J$. spicigera extracts, the Raman spectrum of indigo occurs in the regions of $545 \mathrm{~cm}^{-1}[\delta(\mathrm{C}=\mathrm{C}-\mathrm{CO}-\mathrm{C})]$ and $1574 \mathrm{~cm}^{-1}$ [v (CC $), v(\mathrm{C}=\mathrm{C}), v$ $(\mathrm{C}=\mathrm{O})$ ], signals that are not present in the Raman spectrum of J. spicigera extracts. It has been reported the presence of anthocyanins such as Kaempferitrina and the glucoside of kaemferol from J. spicigera leaves as well as cryptoxanthin, $\beta$-sistoterol, $3 \beta$-glucosyl-o-sitosterol and allantoin $[1 ; 2]$. Comparing the Raman spectra of the extracts of J. spicigera with that of anthocyanins and anthocyanidins, major differences were observed in the regions of 1645-1350 $\mathrm{cm}^{-1}$ and 500-900 $\mathrm{cm}^{-1}$. In the Raman spectrum of J. spicigera, no peaks were observed in the region of $1645 \mathrm{~cm}^{-1}$ and the band in the region of $1330 \mathrm{~cm}^{-1}$ is shifted to $1320 \mathrm{~cm}^{-1}$ region where the spectrum of kaemferol is reported. On the other hand, the presence of glycosylated molecules is shown as well as bands with different intensities, in addition to the presence of a peak at 580 $\mathrm{cm}^{-1}$, which does not correspond to the Raman spectrum for kaemferol. Bands were also detected in the region $400-600 \mathrm{~cm}^{-1}$ in the Raman spectrum as well as bands of the Surface Enhanced Raman spectrum (SERS), which coincides with the reported bands for quercetin and that are attributed to the interaction of catechol and flavonoids with metal nanoparticles; those bands are not found in the Raman spectrum of quercetin in ethanolic solution.

\section{Pigments for foods}

The FDA defines a coloring substance as any dye or pigment obtained from plants, animals, minerals or any other source capable of coloring foods, drugs or cosmetics [44]. In Mexico, the Ministry of Health through the Mexican Official Standard [45], defines a coloring substance as any material or mixture that imparts color to another material which can be obtained by a process of synthesis or extraction or separation from animal, vegetable or mineral sources. Currently 
there is an interest in the use of naturally occurring chemical compounds from biomaterials. Parts of plants (leaves, flowers, fruits, seeds, stems, and roots) are important source of natural colors such as anthocyanins and flavonoids. The content of flavonoids in parts of J. spicigera has attracted the attention of a number of researchers. Pavon-García et al. [15] found a way of obtaining encapsulated J. spicigera aqueous extract using different combinations of gums: Arabic gum, mesquite gum and maltodextrin - mesquite gum. Encapsulation was intended to avoid degradation of the pigments and color loss or chemical deterioration. They found that the best condition for encapsulation of the $J$. spicigera aqueous extract was the combination of mesquite gum-maltodextrin $(1: 1 \mathrm{w} / \mathrm{w})$.

\section{Final remarks}

In this work, a compiling of J. spicigera information about pharmacological and dyeing properties was performed. Knowledge of plant components represents an opportunity for prevention and control of certain diseases; therefore, a number of researchers have demonstrated the pharmacological properties of J. spicigera throughout various scientific studies in Mexican traditional medicine. It has been shown that this plant has important pharmacological properties used to cure infectious and parasitic diseases as well as other type of diseases that are of major problem in the public health in Mexico and around the world, including cancer, leukemia and diabetes. J. spicigera has also dyeing properties that have been used since ancient times for the decoration of basketry and dyeing of fabrics and crafts. Knowledge of such properties can not only preserve the plant, but also allows use in food processing, where exploratory studies are in their early phases of using $J$. spicigera extracts as a natural colorant in foods as well as a source of natural antioxidants.

\section{List of Abbreviations}

${ }^{1} \mathrm{H}-\mathrm{NMR}$, nuclear magnetic resonance; GC-S, Glasgow Coma Scale; UV, ultraviolet; TYIS33, Giardia lamblia culture medium; CD-1®, cluster of differentiation 1; T47D, human ductal breast epithelial tumor cell line; HeLa, an immortal cell type line; ED, effective dose; MCF-7, a breast cancer cell; LNCaP, are androgen-sensitive human prostate adenocarcinoma cells; HIV, human immunodeficiency virus; FDA, Food and Drug Administration; IC $_{50}$, half maximal inhibitory concentration.

Competing interests: Authors do not have financial interests or conflicts of interest.

Authors' Contributors: The two authors contributed to this review.

Acknowledgements: Itzamná Baqueiro-Peña would like to thank to the National Council of Science and Technology (CONACyT) in Mexico for the support granted for her postdoctoral fellowship.

\section{REFERENCES}


1. Euler KL, Adam M: Isolation of Kaempferitrin from Justicia spicigera. J Nat Prod 1982, 45:220-222.

2. Domínguez XA, Achenbach H, González C, Ferré-D’Amare A: Estudio Químico del "Muitle" (Justicia spicigera). Rev Latinoam Quim 1990, 21(3-4):142-143.

3. Sepúlveda-Jiménez G, Reyna-Aquino C, Chaires-Martínez L, Bermúdez-Torres K, Rodríguez-Monroy M: Antioxidant Activity and Content of Phenolic Compounds and Flavonoids from Justicia spicigera. J Biol Sci 2009, 9 (6):629-632.

4. Herrera-Arellano A, Jaime-Delgado M, Herrera-Álvarez S, Oaxaca-Navarro J, SalazarMartínez E: Uso de terapias alternativa/complementaria en pacientes seropositivos a VIH. Revista Médica del Instituto Mexicano del Seguro Social (Mexico) 2009, 47(6):651-658.

5. Andrade-Cetto A, Heinrich M: Mexican plants with hypoglycaemic effect used in the treatment of diabetes. J Ethnopharmacol 2005, 99:325-348.

6. Ortíz-Andrade R, Cabañas-Wuan A, Arana-Argáez VE, Alonso-Castro AJ, Zapata-Bustos R, Salazar-Olivo LA, Domínguez F, Chávez-M, Carranza-Alvarez C, García-Carranca, A: Antidiabetic effects of Justicia spicigera Schltdl (Acanthaceae). J Ethnopharmacol 2012, 143(2):455-462.

7. Cáceres-Cortés JR, Cantú-Garza FA, Mendoza-Mata MT, Chávez-González MA, RamosMandujano G, Zambrano-Ramírez IR: Cytotoxic Activity of Justicia spicigera is inhibited by bcl-2-Proto-oncogene and Induces Apoptosis in a Cell Cycle Dependent Fashion. Phytother Res 2001, 15:691-697.

8. Vega-Ávila E, Espejo-Serna A, Alarcón-Aguilar F, Velasco-Lezama R: Cytotoxic activity of four Mexican medicinal plants. Proceedings of the Western Pharmacology Society 2009, 52:78-82.

9. Jacobo-Salcedo MR, Alonso-Castro AJ, Salazar-Olivo LA, Carranza-Alvarez C, GonzálezEspindola LA, Domínguez F, Maciel-Torres SP, García-Lujan C, González-Martínez MR, Gómez-Sánchez M, Estrada-Castillón E, Zapata-Bustos R, Medellín-Milán P, GarcíaCarrancá A: Antimicrobial and cytotoxic effects on Mexican medicinal plants. Natural Prod Commun 2011, 6(12):1925-1928.

10. Fernández-Pomares C, Bravo-Ávila M, Muñoz-Muñiz O, Juárez-Aguilar E, DomínguezOrtíz MA, Hernández-Aguilar ME: Antiproliferative activity of the polar extract of Justicia spicigera on LNCaP cells. Cancer Prev Res 2010, 3(12 Suppl):B50.

11. Cáceres A, Menéndez H, Méndez E, Cohobón E, Samayoa BE, Peralta E, Carrillo G: Antigonorrhoeal activity of plants used in Guatemala for the treatment of sexually transmitted diseases. J Ethnopharmacol 1995, 48:85-88.

12. Peraza-Sánchez SR, Poot-Kantún S, Torres-Tapia LE, May-Pat F, Simá-Polanco P, CedilloRivera R: Screening of Native Plants from anducatan for anti-Giardia lamblia Activity. Pharm Biol 2005, 43(7):594-598.

13. Ibarra-Moreno S, Ibarra-Velarde F, Ávila-Acevedo JG: Obtaining the Minimum Lethal dose against Fasciola hepatica in vitro using plant extract hexanes with Fasciolicide activity and toxicity evaluation on CD1 male mice. Am J Plant Sci 2012, 3:1-5.

14. Casanova-González E, García-Bucio A, Ruvalcaba-Sil JL, Santos-Vásquez V, Esquivel B, Falcón T, Arroyo E, Zetina S, Roldán ML, Domingo C: Surface - enhanced Raman spectroscopy spectra of Mexican Dyestuffs. J Raman Spectrosc 2012, 43(11):1551-1559. 
15. Pavón-García LM, Pérez-Alonso C, Orozco-Villafuerte J, Pimentel-González DJ, Rodríguez- Hueso ME; Vernon-Carter EJ: Storage stability of the natural colorant from Justicia spicigera microencapsulated in protective colloids blends by spray-drying. Int J Food Sci Technol 2011, 46:1428-1437.

16. Arellano-Rodríguez JA, Flores-Guido JS, Tun-Garrido J: Acantaceas. In: Nomenclatura, forma de vida, uso, manejo y distribución de las especies vegetales de la Península de Yucatán. Yucatan, Mexico: Universidad Autónoma de Yucatán; 2003:4-6.

17. UNAM: Biblioteca digital de la medicina tradicional mexicana [http://www.medicinatradicionalmexicana.unam.mx/monografia.php?1=3\&t=Muicle\&id=79 81]

18. Mendoza-Zúñiga M: Establecimiento de cultivos celulares de Justicia spicigera Shulth. Thesis. Universidad Autónoma Metropolitana-Iztapalapa, México D.F (México); 2010.

19. Daniel TF, Acosta-Castellanos S: Acanthaceae. Flora del Bajío y de regiones adyacentes. Edited by Rzedowski-Rotter J, Calderón-de-Rzedowski G. Pátzcuaro, Michoacán, Mexico: Instituto de Ecología; 2003.

20. Osuna-Torres L, Tapia-Pérez ME, Aguilar-Contreras A: Justicia spicigera Schldl. (Acanthaceae). Plantas medicinales de la medicina tradicional mexicana para tratar afecciones gastrointestinales. Barcelona, España: Publicacions Edicions de la Universitat de Barcelona; 2005.

21. García-Márquez E, Guerrero-Roman A, Pérez-Alonso C, Cruz - Sosa F, Jiménez-Alvarado R, Vernor-Carter EJ: Effect of solvent-temperature extraction conditions on the initial antioxidant activity and total phenolic content of muitle extracts and their decay upon storage at different pH. Revista Mexicana de Ingeniería Química (Mexico) 2011, 11(1):110.

22. Yadav N, Vasudeva N, Singh S, Sharma S: 2007. Medicinal properties of genus Chenopodium Linn. Nat Prod Rad 2007, 6(2):131-134.

23. Madaleno MI: Etno-Farmacología en Iberoamérica, una alternativa a la globalización de las prácticas de cura. Cuadernos Geográficos (Spain) 2007, 41:61-95.

24. Alonso-Castro AJ, Ortíz-Sánchez E, Domínguez F, Arana-Argáez V, Juárez-Vázquez MC, Chávez M, Carranza-Álvarez C, Gaspar-Ramírez O, Espinoza-Reyes G, López-Toledo G, Ortíz-Andrade R, García-Carranca A: Antitumor and immunomodulatory effects of Justicia spicigera Schltdl (Acanthaceae). J Ethnopharmacol 2012, 141(3):888-894.

25. Andrade-Cetto A: Ethnobotanical study of the medicinal plants from Tlanchinol, Hidalgo, Mexico. J Ethnopharmacol 2009, 122:163-171.

26. Peña-Agüero B: Usos y aplicaciones del muicle (Justicia spicigera Schelect et Schdl). Certified in Medicina Tradicional Mexicana. Universidad del Estado de Morelos, Morelos, Mexico; 2010.

27. Heinrich M, Ankli A, Frei B, Weimann C, Sticher O: Medicinal plants in Mexico: Healers, consensus and cultural importance. Soc Sci Med 1998, 47(11):1859-1871.

28. Perusquia M, Mendoza S, Bye R, Linares E, Mata R: Vasoactive effects of aqueous extracts from five Mexican medicinal plants on isolated rat aorta. J Ethnopharmacol 1995, 46:63-69. 
29. Vázquez F: El incremento de las infecciones de transmisión sexual en el siglo XXI: nuevos retos y aparición de nuevas patologías. Enfermedades Infecciosas y Microbiología Clínica (Mexico) 2011, 29(2):77-78.

30. Rosas-Piñon Y, Mejia A, Díaz-Ruíz G, Aguilar MI, Sánchez-Nieto S, Rivero-Cruz F: Ethnobotanical survey and antibacterial activity of plants used in the Altiplane region of Mexico for the treatment of oral cavity infections. J Ethnopharmacol 2012, 141:860- 865.

31. Vega-Ávila E, Tapia-Aguilar R, Reyes-Chilpa R, Guzmán-Gutiérrez SL, Pérez-Flores J, Velasco-Lezama R: Actividad antibacteriana y antigúngica de Justicia spicigera. Rev Latinoam Quim 2012, 40(2):75-82.

32. Faubert G: Immune Response to Giardia duodenalis. Clin Microbiol Rev 2000, 13(1):3454.

33. Ponce-Macotela M, Rufino-González, De la Mora-de la Mora JI, González-Maciel A, Reynoso-Robles R, Martínez-Gordillo MN: Mortality and morphological changes in Giardia duodenalis induced by exposure to ethanolic extracts of Justicia spicigera. Proceedings of the Western Pharmacology Society 2001, 44:151-152.

34. American Diabetes Association (ADA). Reflects on 2008 accomplishments in the fight against diabetes and looks ahead to challenges in 2009. [http://www.diabetes.org/newsroom/press-releases/2009/american-diabetesassociation-2009.html.]

35. Zeichner-Gancz I, Candelaria M: Cáncer de mama: Un problema de Salud. Cancerología (Mexico) 2006, 1:143-145.

36. López-Saavedra A, Lizano-Soberón, M. Cáncer cérvicouterino y el virus del papiloma humano: La historia que no termina. Cancerología (Mexico) 2006, 1:31-55.

37. Jiménez-Ríos MA, Solares-Sánchez M, Martínez-Cevera P, Aguilar-Ponce JL, MartínezCedillo J, Hinojosa-Gómez J, River-Rubí L, Zamora-Moreno J: Cáncer de Próstata. Cancerología (Mexico) 2011, 6:13-18.

38. Ojeda-Tovar J, Balbuena-Martínez M, Barbosa-Ibarra AA, Cervera-Ceballos E, CorralesAlfaro C, Espinoza-Zamora JR, Labardini-Méndez JR, López-Navarro OG, Medina-Pérez C, Ramírez-Ibargüen AF, Rivera-Vera S, Sánchez-Guerrero SA, Siñani-Cárdenas M, Zapata-Canto NP, Candelaria-Hernández M, Cortés-Franco J: Leucemia Aguda Mieloblástica. Cancerología (Mexico) 2011, 6:99-102.

39. Jiménez-Bustamante J, Loja-Orpeza D, Ruíz-Sembla E, Maco V, Marcos L, AvilesGonzaga R: Fasciolasis hepática: ¿Un problema diagnóstico?. Revista de Gastroenterología del Perú 2001, 21(2):148-162.

40. Hernández-Ramos LM: Plantas para la producción y decoración de cestería de las comunidades Nahuas: Alahualtitla y Hueycuatitla de los municipios de Chicontepec y Benito Juárez Veracruz. BS Thesis Universidad de Veracruz, Facultad de Biología; 2009.

41. De Ávila A: Tejer el Arcoíris: Colorantes en el mundo. Museo Textil de Oaxaca. Mexico[http://www.museotextildeoaxaca.org.mx/admin/media/images/expo_pdf_6.pd]

42. Trueba-Sánchez S: Plantas tintóreas de Soledad Atzompa, Veracruz, México. BS Thesis. Universidad de Veracruz. Facultad de Biología (Mexico); 2008. 
43. Watson R: Mexican Fugitives: A preliminary investigation of purple in Torner collection. A poster presented to $32^{\text {nd }}$ Annual Meeting of the American Institute for Conservation of Historic and Artistic Works. Washington, D.C. USA. 2004.

44. Contento-Salcedo AM: Nuevos métodos fotométricos y cromatográficos para la determinación de colorantes rojos en alimentos. PhD Thesis. Universidad de Castilla de la Mancha, España (Spain); 1997.

45. NOM-118-SSA1-1984: Norma Oficial Mexicana. Bienes y servicios. Materias primas para alimentos, productos de perfumería y belleza, colorantes y pigmentos inorgánicos. Especificaciones Sanitarias. 1984. 